\title{
Alteration and fluid characteristics of a mineralised shear zone in the Lower Palaeozoic of the Anglo-Brabant belt, Belgium
}

\author{
K. Piessens ${ }^{\mathrm{a}, *}$, P. Muchez ${ }^{\mathrm{a}}$, W. Viaene ${ }^{\mathrm{a}}$, A. Boyce ${ }^{\mathrm{b}}$, W. De Vos ${ }^{\mathrm{c}}$, M. Sintubin ${ }^{\mathrm{d}}$, \\ T. Debacker ${ }^{\mathrm{e}}$ \\ ${ }^{\text {a } F y s i c o-c h e m i s c h e ~ G e o l o g i e, ~ K . U . ~ L e u v e n, ~ C e l e s t i j n e n l a a n ~ 200 C, ~} 3001$ Heverlee, Belgium \\ ${ }^{\mathrm{b}}$ Isotope Geosciences Unit, SURRC, Rankine Avenue, East Kilbride, Glasgow G75 OQF, UK \\ ${ }^{\mathrm{c}}$ Belgian Geological Survey, Jennerstraat 13, 1000 Brussels, Belgium \\ ${ }^{\mathrm{d}}$ Laboratorium voor Algemene Geologie, K.U. Leuven, Redingenstraat 16, 3000 Leuven, Belgium \\ ${ }^{\mathrm{e}}$ Vakgroep Geologie \& Bodemkunde, Universiteit Gent, Krijgslaan 281 S8, 9000 Gent, Belgium
}

\begin{abstract}
In the Lower Palaeozoic rocks of the Brabant Massif (Belgium), a recently discovered polysulphide mineralisation is intimately related to a high strain zone. Data from drillings, completed with outcrop data allow a detailed investigation of mineralisation, alteration and fluid characteristics of this high strain zone, currently interpreted as a low-angle reverse shear zone and attributed to the main Early to early Middle Devonian Acadian deformation event. Ore mineralisation occurred synkinematically and was closely associated with the shear zone. Low saline $\mathrm{H}_{2} \mathrm{O}-\mathrm{CO}_{2}\left(-\mathrm{CH}_{4}\right)-\mathrm{NaCl}$ fluids with temperatures $>260^{\circ} \mathrm{C}$ were involved in the hydrothermal circulation, which caused alteration of the host rock and extensive sericitisation in the shear zone. Isotope data and the general setting indicate a metamorphic-driven system. (C) 2000 Elsevier Science B.V. All rights reserved.
\end{abstract}

Keywords: Lower Palaeozoic massif; fluid flow; shear zone; syntectonic mineralisation

\section{Introduction}

Some mineralisations can spatially be related to shear zones, which are the product of strain localisation. Examples of these are the many Archean lode gold deposits and comparable deposits of younger age. These are in general related to steeply dipping structures, and their economic importance has led to several studies regarding the relation of strain localisation, alteration and mineralisation.

Low-angle shear zones are quite common, but mineralisations associated with these zones seem to

\footnotetext{
* Corresponding author. Fax: + 32-16-327981.

E-mail address: kris.piessens@geo.kuleuven.ac.be (K. Piessens).
}

be rare. Examples of these are the gold bearing HydeMacreas Shear Zone in New Zealand, the Cowarra gold deposit in New South Wales, and the polymetallic mineralisation near Sint-Pieters-Kapelle, located in the Lower Palaeozoic Brabant Massif (Belgium). The latter example will be discussed as a case study in which time and spatial relationships between deformation, veining, alteration and mineralisation are investigated.

\section{Geological setting}

Deformation and metamorphism of the Brabant Massif occurred during the Early to early Middle Devonian (Van Grootel et al., 1997). The study area 


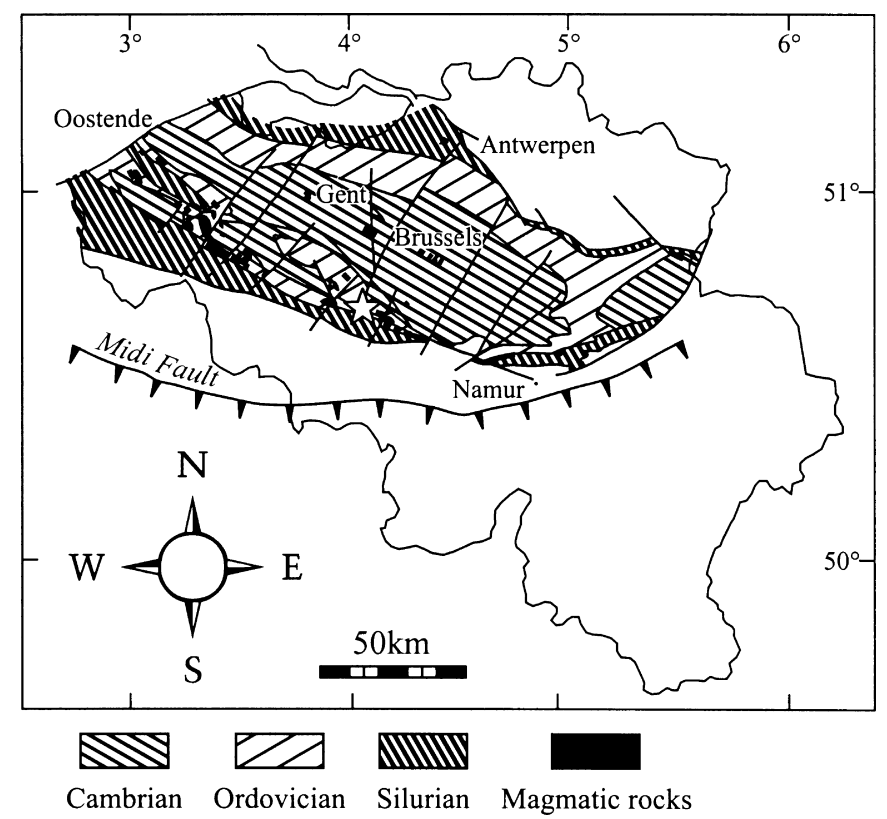

Fig. 1. Subcrop map of the Brabant Massif. The area studied (Sint-Pieters-Kapelle) is indicated with a star.

is located at the southern edge of the Brabant Massif (Fig. 1), in strata currently assigned to the Tremadoc (Lower Ordovician; Verniers, personal communication, 1997). The deposits consist of an alternation of siltstones and pelites, which resulted from turbidity flows, and few interstratified magmatic rocks. Magmatic rocks are often present in the southern part of the Brabant Massif, but are generally of Ashgill age, in contrast with the probably older volcanic rocks in the study area. The folds in the southwestern part of the Brabant Massif are commonly verging towards the SSW and are associated with a cleavage that generally dips towards the NNE (cf. Sintubin, 1999).

\section{Strain localisation}

To explain the variation in fold hinge line orientations, the sigmoidal change of the cleavage dip across the outcrop area and in drilling B6 and the localised occurrence of stretching lineations, Debacker (1997) invoked the presence of a low-angle reverse shear zone in the study area. The local tectonic transport direction is towards the $\mathrm{SW}\left(210^{\circ}\right)$. Shearing is contemporaneous with folding.

In order to quantify the sigmoidal change, cleavage dips were measured on non-oriented cores from five drillings (B4-B8), with a total length of $1410 \mathrm{~m}$. Two of these drill holes have been logged using a borehole televiewer (BHTV). The correlation between the two methods shows that the dip direction of the cleavage remains fairly constant to the NE, varying between 20 and $80^{\circ}$, confirming the field observations. The mean dip of the cleavage changes with an order of magnitude of $0.01-0.1 \% \mathrm{~m}$ over intervals of $50 \mathrm{~m}$ or more.

A more direct observation between strain localisation and the evolution of the cleavage dip can be observed in drilling B6, where microscopic and macroscopic deformation features are more pronounced in the interval characterised by the lowest cleavage dips. The deformation features are generally less pronounced in the other drillings, suggesting less total or less localised strain.

\section{Mineralisation}

The polysulphide mineralisation took place during 


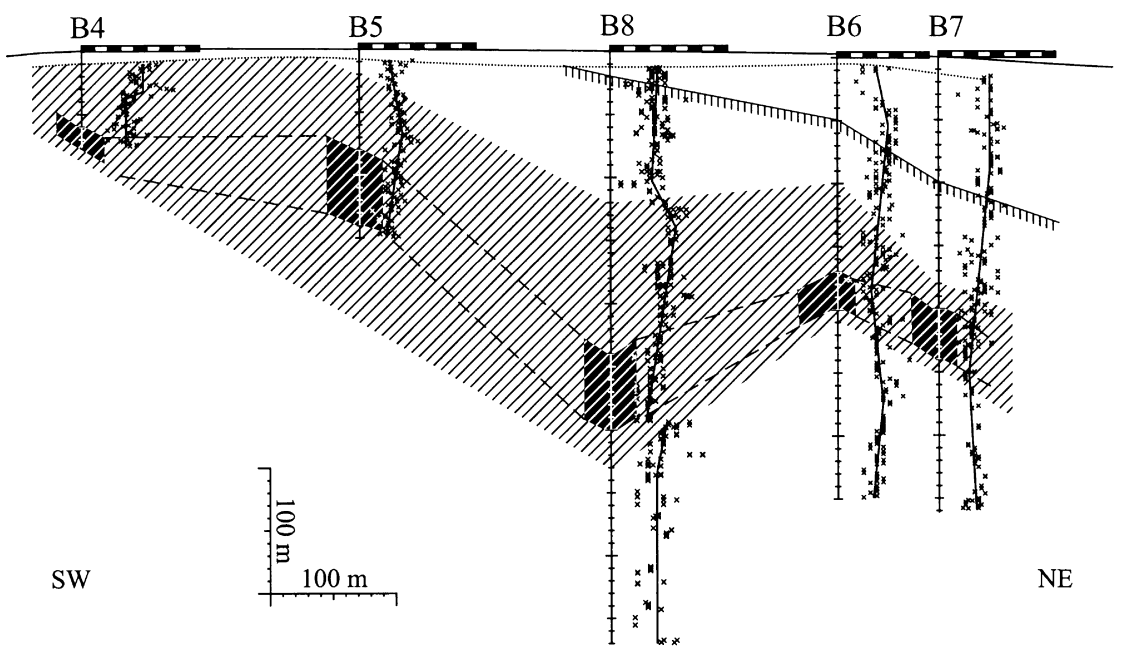

Fig. 2. The location of five drillings in a profile. Drillings B4-B8 line up in SW-NE direction; B6 has been projected about $150 \mathrm{~m}$ from the SE along the structural trend. Both the surface topography and the topography of the massif have been drawn. The macroscopic cleavage dips, and the inferred trends, are shown along the drillings, with a scale-bar with units of $10^{\circ}$ at the top (increasing left to right). The hatched-area indicates the intensely sericitic altered rocks, derived from SWIR-spectra, interpolated between the drillings. The line with vertical hatching shows the top limit of recognisable hydrothermal alteration, coinciding with the top of mineralisation. The black zone shows the most important zones with low cleavage dips, probably coinciding with zones of localised strain. A correlation of these zones results in an, at this scale, unlikely zigzag pattern.

several stages, ranging from early diagenetic pyrite to late goethite (Piessens et al., 1999). Only the two main stages, both related to the deformation, will be discussed here. The first main stage consists of pyrite veinlets, which formed at the onset of ductile deformation. They are a few millimetres thick and generally follow the cleavage or bedding planes. These veins have been deformed due to the protracted development of the cleavage fabric, resulting in the boudinage of veins parallel to the cleavage and small folds in veinlets at higher angle to the cleavage. The in part cleavage-parallel attitude, and their deformation indicate a syntectonic development of the veins.

The pyrite veinlets are cut by mineralised quartz veins, representing the second major phase of sulphide precipitation. Some of the quartz veins formed parallel to the cleavage. The earliest sulphides in the quartz veins are pyrite, marcasite and more rarely arsenopyrite. These sulphides have partly been replaced by sphalerite, chalcopyrite and galena, which can be present in pressure shadows around pyrite grains. This texture indicates precipitation during deformation.

In the drillings B4, B5 and B8, sulphides are present throughout the entire length of the drilling, whereas the upper portions of B6 and B7 are devoid of sulphides, with the exception of some minor pyrite (Fig. 2).

\section{Alteration}

The lithology at Sint-Pieters-Kapelle is relatively uniform (turbiditic siltstones and pelites) with the exception of the few volcanic intercalations. The least altered rocks show evidence of regional greenschist metamorphism. Intensely altered siltstones and pelites are white due to silicification and sericitisation. Detailed macroscopic and microscopic description, assisted by short wave infrared (SWIR) spectra and $\mathrm{X}$-ray diffraction, allows to distinguish several alteration zones between the least and most altered end members. These zones can easily be correlated between drillings, showing an overall alteration pattern in which the strongest sericitised rocks occur deeper in the NE than in the SW (shaded zone in Fig. 2).

The alteration is syntectonic. The chlorite-muscovite slickenfibers on the cleavage planes, which formed during shear along these planes, show similar 
variations as the mineralogy of the altered host rock. The slickenfibers are often intergrown with $\mathrm{Cu}-\mathrm{Pb}-$ $\mathrm{Zn}$ sulphides in strain shadows around pyrite grains. The distribution of sulphides is limited to the altered rocks.

A comparison between the alteration and cleavage dip patterns shows that significant zones of low cleavage dips, interpreted as parts of the shear zone (Debacker, 1997), fall within the sericitic zone. The location of higher strained zones with a more limited extent within a broader altered zone allows a twofold interpretation. Firstly an extensive alteration halo developed around a localised shear zone or secondly an erratic strain localisation present in a shear zone comprising the sericitic zone.

In the first case, the highest strained zones would belong to one, more or less planar structure. This was verified by constructing the hypothetical trace of the shear zone using a graphical and statistical estimation of the vertical offsets between the cleavage patterns. The zigzag pattern (Fig. 2) is too pronounced in a profile at this scale. The second explanation also implies an irregular outline, but a broader shear zone can accommodate for this more easily. The higher strained zones themselves do not have to correlate.

\section{Hydrothermal fluids}

The composition, temperature and origin of the fluids, canalised within the shear zone, were studied by microthermometry and Raman spectroscopy of fluid inclusions in vein quartz and by isotope geochemistry.

The vein quartz contains mixed aqueous-gaseous fluid inclusions. At room temperature, two phases $(\mathrm{L}+\mathrm{V})$ are present. The lowering of the melting point of $\mathrm{CO}_{2}$ down to $-68^{\circ} \mathrm{C}$ in the fluid inclusions, clathrate dissociation temperatures up to $+15^{\circ} \mathrm{C}$ and Raman spectroscopy indicate the presence of $\mathrm{CH}_{4}$ in addition to $\mathrm{CO}_{2}$. In some inclusions, eutectic melting could be observed around $-20^{\circ} \mathrm{C}$, indicating the presence of $\mathrm{NaCl}$. The fluids trapped therefore belong to the $\mathrm{H}_{2} \mathrm{O}-\mathrm{CO}_{2}-\mathrm{CH}_{4}-\mathrm{NaCl}$ system. The absence of a separate $\mathrm{CO}_{2}-\mathrm{CH}_{4}$ liquid phase at room temperature and during cooling is attributed to the low density of the fluids. This has been confirmed by density calculations. Raman spectroscopy shows that the $\mathrm{CH}_{4}$ content of the gas phase can be up to $55 \%$. The ice melting temperatures suggest salinities $<7 \mathrm{wt} \%$ $\mathrm{NaCl}_{\text {eq. }}$.

In most samples, decrepitation of fluid inclusions occurs at temperatures $>250^{\circ} \mathrm{C}$. Most of them homogenise between 260 and $290^{\circ} \mathrm{C}$, implying a formation temperature of $>260^{\circ} \mathrm{C}$. The existence of syntectonic veins parallel to the cleavage planes implies a fluid pressure close to lithostatic.

The oxygen isotopic composition of the ambient mineralising fluid calculated from the $\delta^{18} \mathrm{O}$ values of quartz and the $T_{\mathrm{h}}$ values of the primary fluid inclusions ranges between 4.1 and $8.4 \%$ (SMOW). The measured $\delta \mathrm{D}$ of the fluid inclusions varies from -70 to $-30 \%$ o (SMOW). These values fall within the field of metamorphic fluids and partly overlap with that of primary or I-type magmatic fluids. The sulphur isotopic composition of pyrite, marcasite, chalcopyrite and sphalerite yields values between 4.7 and $10.6 \%$, far from the assumed I-type magmatic values.

\section{Discussion and conclusions}

All data support the syntectonic nature of the mineralisation at Sint-Pieters-Kapelle (Piessens et al., 1999), but the origin of the ore and the fluids has been a matter of debate. A primary relation with VMS or remobilisation of such a deposit and other magmatic related sources have been proposed, mainly based on the presence of magmatic rocks in the Brabant Massif.

Only part of the $\delta^{18} \mathrm{O}-\delta \mathrm{D}$ data and none of the $\delta^{34} \mathrm{~S}$ correspond to I-type magmatic fluids, which can therefore be excluded as a dominant source. Isotope data are compatible with both S-type magmatic and metamorphic fluids. A magmatic hydrothermal system would imply contemporaneous volcanic and/ or intrusive activity. All known magmatism in the Brabant Massif is at least 30 Ma older than the mineralisation. Moreover, this magmatism is related to subduction, which is typically dominated by I-type magmas. A metamorphic-driven system, on the other hand, fits well within the tectonometamorphic frame of the deposit. This is further supported by the presence of $\mathrm{CH}_{4}$ in fluid inclusions. 
The alteration and mineralisation pattern in SintPieters-Kapelle is space and time related to a high strain zone, interpreted as a shear zone. The trace of this shear zone has been constrained by the alteration pattern. The mineralising fluids are likely of metamorphic origin.

\section{Acknowledgements}

ANRE (Division of Natural Resources and Energy) of the Flemish community funded this three year research project. Additional funding is provided by the Fund of Scientific Research of Flanders (Belgium) project 9.0274.99. The cores studied are the property of the company Terex and the Flemish community. We are grateful to both for the permission to publish the results. We also thank E. Burke for carrying out the Raman spectroscopic analyses at the Free University of Amsterdam. The thin sections and the doubly polished wafers were carefully prepared by H. Nijs.
$\mathrm{Ph}$. Muchez is a Senior Research Associate, M. Sintubin is a Postdoctoral Fellow and T. Debacker is a Research Assistant of the Fund of Scientific Research of Flanders (Belgium).

\section{References}

Debacker, T., 1997. Folds trending at various angles to the transport direction in the Marcq area, Brabant Massif, Belgium. MSc thesis, Imperial College, London.

Piessens, K., Muchez, Ph., Viaene, W., De Vos, W., 1999. Syntectonic polysulphide mineralisation in the Brabant Massif, Belgium. In: Stanley, C. (Ed.). Mineral Deposits: Processes to Processing, Balkema, Rotterdam, pp. 963-966.

Sintubin, M., 1999. Arcuate fold and cleavage patterns in the southeastern part of the Anglo-Brabant fold belt (Belgium): tectonic implications. Tectonophysics 308, 81-97.

Van Grootel, G., Verniers, J., Geerkens, B., Laduron, D., Verhaeren, M., Hertogen, J., De Vos, W., 1997. Timing of magmatism, foreland basin development, metamorphism and inversion in the Anglo-Brabant fold belt. Geol. Mag. 134, 607-616. 